\title{
Research on Accounting Measure based on Fair Value
}

\author{
Wang Hongni
}

Dongying Vocational College, Dongying, Shandong, 257091

\begin{abstract}
Fair value is the inevitable trend of the development of accounting measurement. China reintroduced fair value conceptand defined the scope of the application of it in 2006 to acceleratethe progress of internationalization of China's accounting standards. This paper analyzes the problems in the application of fair value in accounting measures, and gives the corresponding measures in order to provide references for the related researchers.
\end{abstract}

KEYWORDS: accounting measure; fair value

\section{INTRODUCTION}

Theoretically speaking, the fair value refers to the value of exchange of assets or liabilities settlement in the even bargain in accordance with the principle of voluntary when both of the transaction parties are familiar with the market. That is to say, the fair value is the assets exchange price or debt clearing settlement pricein the principle of fairness.

Fair value has the following characteristics:

(1) Fair value is formed in the fair transaction. That is to say, the transaction the parties are voluntary and familiar with the situation. At the same time, the amount of transaction is fair, is the agreed.The formation in the forced transaction or the liquidation process transaction amount it cannot be fair value.

(2) The object of fair value measurement is comprehensive. That fair value is the fair value of assets or liabilities, not only have the fair value of assets, liabilities, also with the fair value.

(3) The formation of the fair value of the market is widespread. National institutions does not have what special requirements on the formation of the fair value of the market environment, as long as there is even bargain in the market environment, then whatever is in active markets or in inactive markets in the form of fair value can.

(4) The fair value measurement is not the simple superposition. The overall value of a superposition system sometimes is far greater than the internal value of individual, a typical example is the goodwill, so for each individual value must be fully evaluated. Fair value is not a kind of measurement attribute.It is a combination of the concept.Historical cost, current cost, current market value, net realizable value, present value are all forms of fair value.

\section{Problems of Accounting Measure based on Fair Value}

Fair value makesaccounting records change from static records to dynamic records. It can objectively reflect the true financial position and operating results. But the fair value in accounting measurement in practice there are still many problems, such as the imperfect market system, the incomplete accounting standards and the unsound governance structure. 


\section{A: Imperfect Market System}

The fair value of the assets and liabilities of the evaluation is based on market information. The primary condition of it's widely introduced is the high degree of the market. China introduced fair value is not successful for the first timein 1998. One of the reasons is that our market economy environment is not mature enough. At present our country's market economies while the fast development, but compared with developed countries, the development of the market economy is not mature, the market economic system is not perfect. For example, some electric energy and other key industries of natural monopoly, it is difficult to form the elements of market perfect competition; China's bond market segmentation phenomenon is serious; the means of production market level, the property market is still in the construction and so on, all these constitute the our country comprehensive implementation of the fair value of the barrier. Accounting supervision system in our country is still not perfect, to adapt to the new environment of market economy credit system has not been established, and resulting in the accounting supervision system is often unable to play its due role. Economic nature of enterprise is diverse in our country's economic system. Among them, the listing Corporation due to legal constraints of the market supervision and information disclosure requirements, while foreign-funded enterprises because of its special investment side, in the aspect of audit supervision and do more specification. Although legally required to accept the business tax and auditing departments of the inspection, many companies will exist undetected or completely in the supervision system as a result of the incomprehensive standardized examination and inspection.

\section{B: Incomplete Accounting Standards}

The applying guideline of fair value is dispread in the new accounting standards. Treasury has issued a special for the fair value of the standards. This has caused some of the fair value of the basic issues, such as the explanation of the concept, measuring method and level, specific confirmation standard, relevant disclosure do not have a unified standard, which makes the application of the fair value of the lack of effective guidance. For example, criteria specified in the trading financial assets full use of fair value measurement, according to the balance sheet balance day trading of financial funds of fair value and book value, increase or reduce the changes in fair value gains and losses, changes in fair value gains and losses eventually transferred to the profit for the year, the total effect of current profits, the fair value of trading financial assets the amount of change in the holding period, the profit and loss or unrealized profit and loss, this should be in the transaction disposal of financial assets, we can really achieve, during the holding period of financial assets, will influence the profit or loss for the current period, apparently causes the current profit empty to add or virtual cut, make profit total distortion. Vulnerability in the criterion of these is for the implementation of profit enterprises to provide a gap manipulation. This also reflects from one aspect that our country is in great need of a complete and regulated system for fair value measurement standards.

\section{C: Unsound Governance Structure}

The management of the company's deliberate fraud may lead to that fair value becomes the enterprise profit manipulation tool. The company's management to the internal control system of deliberate fraud and the company is not strict, internal management 
structure is not perfect relevant. At present, the ownership structure of China's listing Corporation China has shares, legal person shares accounted for the major share of the corporate governance structure, resulting in the general meeting of shareholders, board of directors of the statutory authority subject to the managers, the internal governance structure is reasonable will lead to failure of the internal control of the enterprises, the ultimate impact of enterprise performance and of vital importance. For example, Enron Corp failures although there are many reasons for direct and indirect, but very strong evidence, the fair value of the third levels of long-term abuse in its play an important role in the collapse. The abuse of fair value of financial fraud and its internal control system led to the serious deficiency.

\section{Solutions to Problems of Accounting Measure based on Fair Value}

\section{A: Improve Market System}

First, we need to cultivate ourfactors market and vigorously develop our country manufacturing data market,regulate financial markets and develop the real estate market.The second is to cultivate the diversified market, the transformation of government functions, to deepen the reform of state-owned enterprises, promote and participate in market competition of various economic forms, encourage individuals to participate in marketing activities to the market main body status. Finally, the formation of the price determined by the market price formation mechanism, establish and perfect the government price system and the related legal system. Market economy is legal economy, in order to ensure the full development of market economy, perfect the market competition, must establish a complete socialist market economy management system of laws and regulations. At the same time, we should strengthen law enforcement and supervision of the masses.

\section{B: OptimizeAccounting Standards}

Currently, the applying guideline of fair value is dispread in the new accounting standards. The relevant norms of fair value lacks of a criterion and frame system.Practice more and more time is dependent on the accounting occupation judgment. But in the current overall quality of accounting personnel in our country is not high, uneven, some good and some bad situations, and relied too much on occupation judgment, a considerable part of China's accounting personnel level may be difficult, moreover enterprises may borrow occupation judgment of the profit manipulation. This obviously and strengthen the purpose of accounting supervision, improve the quality of accounting information of our country's current contrary. In view of the current regulations on the impairment of assets and the determination of the fair value and so on are lack of system and exposed in practice many problems, should further improve assets impairment provision and reversal, determining fair value standards, to the management of listing Corporation accounting professional judgment abuse from accounting norms is a priority. In this, China can learn from international practice, by the Ministry of finance from the theory circle and practice circle related experts, composed of standard setting group, formulate relevant fair value measurement standard. The new guidance of the fair value should include the detailed criterion of definition, scope of application, confirming principle and estimation methods. Moreover, the concrete operation and relevant supplementary description should be detailed in the instructions. 


\section{C: Enhance Governance Structure}

A good governance structure is the guarantee of good performance and high quality accounting. Chinese enterprises should change the status of the chairman of the board governance structure. The board of supervisors is subject to the managers, the establishment of the internal governance structure to the chairman of the board for the center. In this governance structure, modest, cautious, conditional to the introduction of fair value, fair value to play better reliability information relevance, accounting. The concrete can be used to improve the system of independent directors, the appropriate adjustment of the general meeting of shareholders rights, strengthen the power of the board of supervisors, to achieve the establishment of the shareholder representative litigation system and other methods. To improve the decision relevance of fair value, it is necessary to further improve the internal control system of enterprises, because the fair value only in a sound internal control system of enterprises can play a good role in it. We should enhance the governance structure to prevent the fair value from becoming the enterprise profit manipulation tool.

\section{Conclusions}

many companies will exist undetected or completely in the supervision system as a result of the incomprehensive standardized examination and inspection. This also reflects from one aspect that our country is in great need of a complete and regulated system for fair value measurement standards.

The abuse of fair value of financial fraud and its internal control system led to the serious deficiency. We should enhance the governance structure to prevent the fair value from becoming the enterprise profit manipulation tool.

\section{REFERENCE:}

[1] Javier Gómez-Biscarri, Germán López-Espinosa. Accounting measures and international pricing models: Justifying accounting homogeneity[J].Journal of Accounting and Public Policy, 2008, 27

[2] Noriaki Okamoto. Fair value accounting from a distributed cognition perspective[J].Accounting Forum, 2014, 38 [3] Neil Fargher, John Ziyang Zhang. Changes in the measurement of fair value: Implications for accounting earnings $[\mathrm{J}]$.Accounting Forum, 2012, 18 